\title{
Attenuation of ultraviolet radiation and photosynthetically active radiation in six Yunnan Plateau lakes of China based on seasonal field investigations
}

\author{
Weilu Wang ${ }^{1,2 \#}$, Xuan Yang ${ }^{1 \#}$, Licheng Huang ${ }^{3}$, Jiang Qin², Qichao Zhou ${ }^{1,2, *}$ \\ ${ }^{1}$ Institute for Ecological Research and Pollution Control of Plateau Lakes, School of Ecology and Environmental Sciences, Yunnan \\ University, Kunming; ${ }^{2}$ Yunnan Key Laboratory of Pollution Process and Management of Plateau Lake-Watershed, Yunnan Research \\ Academy of Eco-environmental Sciences, Kunming; ${ }^{3}$ Kunming Institute of Plateau Lake Dianchi, Kunming, China
}

\#These authors contributed equally (co-first authors).

\begin{abstract}
Solar radiation is a primary driver affecting several physical, chemical and biological processes in lake ecosystems. The attenuation of sunlight in water is directly controlled by optically active substances. Here, the seasonal and interlake heterogeneities of the diffuse attenuation coefficients $\left(K_{\mathrm{d}}(\lambda)\right)$ of ultraviolet radiation (UVR) and photosynthetically active radiation (PAR) were studied based on field investigations in six Yunnan Plateau lakes (i.e., Chenghai, Dianchi, Erhai, Fuxian, Lugu and Yangzong) of China, October 2014-July 2016. The results revealed that $K_{\mathrm{d}}(\lambda)$ generally increased with decreasing wavelength and increasing trophic state and that $K_{\mathrm{d}}(\mathrm{UVR})$ presented higher interlake heterogeneity than $K_{\mathrm{d}}(\mathrm{PAR})$. The interlake heterogeneity surpassed the seasonal heterogeneity of $K_{\mathrm{d}}(\lambda)$, whereas the intralake seasonal heterogeneity, which is related to the lake trophic state and solar spectrum, was obvious. Although the main factors affecting $K_{\mathrm{d}}(\lambda)$ were chromophoric dissolved organic matter (CDOM) and phytoplankton in general, the interlake heterogeneity was found. In eutrophic, turbid shallow Lake Dianchi, CDOM primarily affected UV-B, whereas total suspended solids (TSS) and/or phytoplankton had important effects on $K_{\mathrm{d}}(\mathrm{UV}-\mathrm{B}), K_{\mathrm{d}}(\mathrm{UV}-\mathrm{A})$ and $K_{\mathrm{d}}(\mathrm{PAR})$. CDOM, TSS and phytoplankton influenced the $K_{\mathrm{d}}(\mathrm{UV}-\mathrm{B}), K_{\mathrm{d}}(\mathrm{UV}-\mathrm{A})$ and $K_{\mathrm{d}}(\mathrm{PAR})$ in the deep mesotrophic Lake Chenghai and Lake Erhai, but the main particulate factors were different between these two lakes. In the deep, oligotrophic clear Lake Fuxian and Lake Lugu, only the significant effect of CDOM on $K_{\mathrm{d}}(\mathrm{UVR})$ in Lake Fuxian was detected. Additionally, the factors affecting $K_{\mathrm{d}}(\lambda)$ in Lake Yangzong were atypical, possibly due to the artificial addition of massive amounts of ferric chloride.
\end{abstract}

\section{INTRODUCTION}

Ultraviolet radiation (UVR, $200-400 \mathrm{~nm}$ ) and photosynthetically active radiation (PAR, 400-700 $\mathrm{nm}$ ) are necessary components of solar radiation, which is the fundamental driving force of lake ecosystems. Because UVC $(200-280 \mathrm{~nm})$ is often completely absorbed by the ozonosphere and the atmosphere, the UVR that reaches the earth surface primarily contains UV-B (280-320 nm) and UV-A (320-400 nm). The joint effects of UVR and PAR

Corresponding author: qchzhou@ynu.edu.cn

Key words: Ultraviolet radiation; photosynthetically active radiation; diffuse attenuation coefficient; interlake heterogeneity; eutrophication; Yunnan Plateau.

Edited by: Michela Rogora, CNR-IRSA, Verbania, Italy.

Received: 1 December 2019.

Accepted: 19 February 2020.

This work is licensed under a Creative Commons Attribution NonCommercial 4.0 License (CC BY-NC 4.0).

${ }^{\circ}$ Copyright: the Author(s), 2020

Licensee PAGEPress, Italy

J. Limnol., 2020; 79(2): 151-163

DOI: 10.4081/jlimnol.2020.1951 regulate numerous physical, chemical, biological and ecological processes in aquatic ecosystems, such as thermal stratification, biogeochemical cycles, primary production, population dynamics and community structure, and even biological damage (Kirk, 2011; Häder et al., 2015). The vertical propagation of sunlight in water is mainly controlled by the incident sunlight intensity and four optically active substances (OASs), namely, pure water, chromophoric dissolved organic matter (CDOM), tripton or non-algal particulates (NAPs), and phytoplankton (Kirk, 2011).

Due to the heterogeneity of OASs, sunlight attenuation varies according to the lake characteristics (De Lange, 2000; Zhang et al., 2011; Rose et al., 2014; Spyrakos et al., 2018). For example, the diffuse attenuation coefficients $\left(K_{\mathrm{d}}(\lambda)\right)$ of UVR and PAR in the Yunnan-Guizhou Plateau lakes are significantly lower than those of lakes in the middle and lower reaches of the Yangtze River (Zhang et al., 2011). Generally, in (clear) lakes at higher elevations, CDOM and phytoplankton contribute more to UVR attenuation (Laurion et al., 2000; Sommaruga and Augustin, 2006; Rose et al., 2009). In these lakes, the contents of CDOM and phytoplankton are evidently low; accordingly, sunlight attenuation becomes increasingly sensitive to variation in the catchment environment that can impact the OASs inputs and their composition and contents in the lake. Moreover, areas at higher elevations receive more UVR (Pfeifer et al., 2006), and the effects of UVR on lake ecosystems may be further intensified due to its deep pen- 
etration. Strong UVR may enhance the photodegradation of CDOM (Du et al., 2016) and the suppression of phytoplankton (Beecraft et al., 2017). However, with the rapid development of the surrounding catchment, many lakes are now affected by eutrophication, which can change the composition and contents of partial OASs, as well as the underwater optical regimes. Song et al. (2018) indicated that eutrophication can promote excess algal growth and organic accumulation and further increase the contents of dissolved organic carbon. Specifically, increasing nutrient levels may promote phytoplankton biomass (Zhou et al., 2016a), leading to increased abundances of autochthonous CDOM (Pacheco et al., 2014; Aparicio et al., 2016; Cory et al., 2016), such as algae-derived components. As a result of atmospheric deposition and rivers flowing into the lake (Mladenov et al., 2011; Zhang et al., 2014; Zhou et al., 2016b), allochthonous CDOM may also increase with increasing trophic state (Zhang et al., 2018; Shang et al., 2019). Moreover, eutrophication (decreased water transparency)-induced deterioration of submerged vegetation can increase the tripton content in shallow lakes due to sediment resuspension (Zhang et al., 2016; Shi et al., 2018).

Lakes of the Yunnan Plateau (YP) are the main components of the Yunnan-Guizhou Plateau Limnetic Region, one of five limnetic regions in China. These lakes are important for the production of the zone and the life of local residents (Zhou et al., 2019). Unfortunately, the trophic states of many YP lakes have increased in recent decades, which has been accompanied by the deterioration of water quality and aquatic vegetation (Zhang et al., 2017; Dong et al., 2018; Zhou et al., 2019). This deterioration is essentially correlated with the underwater optical regimes of the lakes. Al- though previous studies have investigated the $K_{d}(\lambda)$ of YP lakes (Zhang et al., 2007b; Zhang et al., 2011; Zhou et al., 2018), more research is needed. Moreover, notably, the solar global radiation and UVR of the YP are spatially and temporally heterogenous (Zhou and Chen, 2008; Wang et al., 2009), and the lakes in this area are located at different elevations and have varied trophic states (Zhou et al., 2019). These characteristics imply that the $K_{\mathrm{d}}(\lambda)$ and its major influencing factors in each lake are different. Therefore, we compared the interlake variations of $K_{\mathrm{d}}(\mathrm{UV}-\mathrm{B})$, $K_{\mathrm{d}}(\mathrm{UV}-\mathrm{A})$ and $K_{\mathrm{d}}(\mathrm{PAR})$, as well as their major influencing factors, in six typical YP lakes with differing lake characteristics (e.g., elevation, depth and trophic state). In addition, this study considered the seasonal heterogeneity of lakes because the attenuation of sunlight may vary among seasons (Brandão et al., 2016; Rose et al., 2019).

\section{METHODS}

\section{Study lake description and field sampling}

A total of six lakes (i.e., Lake Chenghai (LCH), Lake Dianchi (LDC), Lake Erhai (LEH), Lake Fuxian (LFX), Lake Lugu (LLG) and Lake Yangzong (LYZ)) with differing basic limnological characteristics, such as latitude and longitude, altitude (from $1503 \mathrm{~m}$ to $2691 \mathrm{~m}$ ), depth (mean, $4.4 \mathrm{~m}$ to $89.6 \mathrm{~m}$; maxima, from $5.9 \mathrm{~m}$ to $155.0 \mathrm{~m}$ ), area (from $31.7 \mathrm{~km}^{2}$ to $309.0 \mathrm{~km}^{2}$ ) and trophic state (from oligotrophic to mesotrophic and eutrophic), were sampled in spring, summer, autumn and winter (Tab. 1). Water samples were collected at a depth of $0.5 \mathrm{~m}$ to determine OASs and other physical-chemical parameters.

Tab. 1. Location and basic limnological parameters of the six sampled lakes on the Yunnan Plateau.

\begin{tabular}{|c|c|c|c|c|c|c|}
\hline Parameters & Lake Chenghai & Lake Dianchi & Lake Erhai & Lake Fuxian & Lake Lugu & Lake Yangzong \\
\hline Latitude $(\mathrm{N})$ & $26^{\circ} 27^{\prime} \sim 26^{\circ} 38^{\prime}$ & $24^{\circ} 40^{\prime} \sim 25^{\circ} 02^{\prime}$ & $25^{\circ} 36^{\prime} \sim 25^{\circ} 58^{\prime}$ & $24^{\circ} 21^{\prime} \sim 24^{\circ} 38^{\prime}$ & $27^{\circ} 41^{\prime} \sim 27^{\circ} 45^{\prime}$ & $24^{\circ} 51^{\prime} \sim 24^{\circ} 58^{\prime}$ \\
\hline Longitude (E) & $100^{\circ} 38^{\prime} \sim 100^{\circ} 41^{\prime}$ & $102^{\circ} 36^{\prime} \sim 102^{\circ} 47^{\prime}$ & $100^{\circ} 06^{\prime} \sim 100^{\circ} 18^{\prime}$ & $102^{\circ} 49^{\prime} \sim 102^{\circ} 57^{\prime}$ & $100^{\circ} 45^{\prime} \sim 100^{\circ} 50^{\prime}$ & $102^{\circ} 58^{\prime} \sim 103^{\circ} 01^{\prime}$ \\
\hline Altitude (m) & 1503 & 1887 & 1973 & 1721 & 2691 & 1771 \\
\hline Mean depth (m) & 25.7 & 4.4 & 10.2 & 89.6 & 40.3 & 19.5 \\
\hline Maximum depth (m) & 35.1 & 5.9 & 20.7 & 155.0 & 93.5 & 30.0 \\
\hline Area $\left(\mathrm{km}^{2}\right)$ & 77.2 & 309.0 & 249.0 & 211.0 & 48.5 & 31.7 \\
\hline $\mathrm{COD}_{\mathrm{Mn}}(\mathrm{mg} / \mathrm{L})$ & $5.23 \pm 0.60$ & $7.97 \pm 0.98$ & $4.47 \pm 0.87$ & $1.53 \pm 0.21$ & $1.50 \pm 0.25$ & $3.81 \pm 0.27$ \\
\hline $\mathrm{TN}(\mathrm{mg} / \mathrm{L})$ & $0.70 \pm 0.12$ & $2.73 \pm 0.63$ & $0.52 \pm 0.50$ & $0.11 \pm 0.05$ & $0.07 \pm 0.04$ & $0.44 \pm 0.18$ \\
\hline $\mathrm{TP}(\mathrm{mg} / \mathrm{L})$ & $0.05 \pm 0.02$ & $0.14 \pm 0.06$ & $0.04 \pm 0.03$ & $0.03 \pm 0.02$ & $0.01 \pm 0.00$ & $0.09 \pm 0.05$ \\
\hline $\mathrm{Chl} a(\mu \mathrm{g} / \mathrm{L})$ & $11.36 \pm 7.81$ & $39.60 \pm 19.10$ & $7.52 \pm 4.34$ & $1.56 \pm 0.62$ & $0.15 \pm 0.17$ & $24.23 \pm 13.54$ \\
\hline$T L I_{\mathrm{C} 4}$ & $46.68 \pm 2.88$ & $62.98 \pm 3.68$ & $40.11 \pm 5.66$ & $22.67 \pm 5.66$ & $8.96 \pm 3.74$ & $48.15 \pm 3.09$ \\
\hline Sampling sites & 9 & 13 & 11 & 16 & 9 & 6 \\
\hline Sampling time & $\begin{array}{l}\text { Oct., 2014; Jan., } \\
\text { Apr., Jul., 2015 }\end{array}$ & $\begin{array}{c}\text { Oct., 2014; } \\
\text { Jan., Apr., Jul., } 2015\end{array}$ & $\begin{array}{c}\text { Oct., 2014; } \\
\text { Jan., Apr., Jul., } 2015\end{array}$ & $\begin{array}{c}\text { Oct., 2014; } \\
\text { Jan., Apr., 2015; } \\
\text { Jul., } 2016\end{array}$ & $\begin{array}{c}\text { Oct., 2014; } \\
\text { Jan., Apr., Jul., } 2015\end{array}$ & $\begin{array}{l}\text { Oct., 2014; } \\
\text { Jan., Apr., 2015; } \\
\text { Jul., } 2016\end{array}$ \\
\hline
\end{tabular}

$C_{C O D_{M n}}$ (mean $\left.\pm S D\right)$, chemical oxygen demand by manganese; TN (mean $\left.\pm S D\right)$, total nitrogen; TP (mean $\left.\pm S D\right)$, total phosphorus; Chl a (mean $\left.\pm S D\right)$, chlorophyll a; $\operatorname{TLI}_{C 4}($ mean $\pm S D)$, comprehensive trophic state index based on four water quality indices: $C O D_{M n}, T N, T P$ and Chl a. Oct., Jan., Apr. and Jul. represent autumn, winter, spring and summer, respectively. 


\section{Underwater irradiance profile measurement}

The underwater downward irradiance of UV-B (305 $\mathrm{nm}, 313 \mathrm{~nm}, 320 \mathrm{~nm}), \mathrm{UV}-\mathrm{A}(340 \mathrm{~nm}, 380 \mathrm{~nm}, 395 \mathrm{~nm})$ and PAR at different depths ranged from 0 to $3.5 \mathrm{~m}$ in the mixed layer were measured by a UV-visible radiation meter (PUV-2500, Biospherical Instruments Inc., USA) at all sampling sites of the six lakes. The $K_{\mathrm{d}}(\lambda)$ was calculated according to equation (1) (Kirk, 2011).

$$
K_{\mathrm{d}}(\lambda)=-\frac{1}{z} \ln \frac{E_{\mathrm{d}}(\lambda, z)}{E_{\mathrm{d}}(\lambda, 0)}
$$

where $K_{\mathrm{d}}(\lambda)$ is the diffuse attenuation coefficient of each solar spectrum (wavelength, $\lambda$ ), and $E_{\mathrm{d}}(\lambda, z)$ and $E_{\mathrm{d}}(\lambda, 0)$ are the values of the downward irradiance of $\lambda$ at a depth of $z \mathrm{~m}$ and just below the surface $(0 \mathrm{~m})$, respectively.

\section{OAS and physical-chemical parameter measurements}

Water samples were filtered through GF/F filter membranes $(0.70 \mu \mathrm{m}$ porosity, Whatman, UK) and then filtered through cellulose filter membranes $(0.22 \mu \mathrm{m}$ porosity, Merck Millipore, Germany) to determine the CDOM absorption. The optical density of CDOM at the wavelength $\lambda(D(\lambda))$ was measured with a range of $200-800 \mathrm{~nm}(1 \mathrm{~nm}$ interval) using a $5 \mathrm{~cm}$ quartz cell on a UV-visible spectrophotometer (UV-2550PC, Shimadzu, Japan). The absorption coefficient of CDOM at the wavelength $\lambda\left(a_{\mathrm{g}}(\lambda)\right)$ was corrected and calculated from $D(\lambda)$ according to equation (2) (Zhang et al., 2007a).

$$
a_{\mathrm{g}}(\lambda)=\frac{2.303\left[D(\lambda)-\frac{D(700) \lambda}{700}\right]}{r}
$$

where $r$ is the cuvette path length in $\mathrm{m}(0.05 \mathrm{~m}$ here $)$. The $a_{\mathrm{g}}(254)$ was selected to characterize the CDOM abundance (Zhang et al., 2014).

Chlorophyll $a$ (Chl $a$, represents phytoplankton biomass), total suspended solid (TSS, includes phytoplankton and NAPs), total nitrogen (TN), total phosphorus (TP) and the chemical oxygen demand by manganese $\left(\mathrm{COD}_{\mathrm{Mn}}\right)$ values were measured according to the standard methods described by the Editorial Board of Water and Wastewater Monitoring and Analysis Methods of the Ministry of Environmental Protection of the People's Republic of China (China, 2002). The four-factor comprehensive trophic state index $\left(T L I_{\mathrm{C} 4}\right.$ involving the four parameters Chl $a$, $\mathrm{TN}$, TP and $\mathrm{COD}_{\mathrm{Mn}}$ ) was calculated for each sample according to equation (3) (Jin and Tu, 1990).

$$
T L I_{\mathrm{C} 4}=\sum_{j=1}^{4} W_{i} \times\left(\mathrm{a}_{j}+\mathrm{b}_{j} \times \ln C_{j x}\right)
$$

where $W_{\mathrm{i}}$ is the weight of each parameter, $\mathrm{a}_{j}$ and $\mathrm{b}_{j}$ are constants related to each parameter, which are obtained from Jin and Tu (1990); $C_{j x}$ is the value of each parameter (i.e., Chl $a, \mu \mathrm{g} / \mathrm{L}$; TN, mg/L; TP, mg/L; $\mathrm{COD}_{\mathrm{Mn}}, \mathrm{mg} / \mathrm{L}$ ).

\section{Statistical analysis}

The multi-independent-sample nonparametric test (Kruskal-Wallis one-way ANOVA, Stepwise step-down), two-way analysis of variance, Spearman correlation and stepwise regression analyses were all conducted using Statistical Product and Service Solutions (SPSS) Statistics (ver. 24.0, IBM, Armonk, NY, USA); for the two-way analysis of variance and the stepwise regression, the data of each dependent variable were transformed by natural logarithm; $\mathrm{P}<0.05$ was considered significant, and $\mathrm{P}<0.01$ was considered extremely significant.

\section{RESULTS}

\section{Variations in $K_{\mathrm{d}}(\mathrm{UV}-\mathrm{B}), K_{\mathrm{d}}(\mathrm{UV}-\mathrm{A})$ and $K_{\mathrm{d}}(\mathrm{PAR})$}

Generally, the average values (mean \pm SD) for all the samples of $K_{\mathrm{d}}(305), K_{\mathrm{d}}(313), K_{\mathrm{d}}(320), K_{\mathrm{d}}(340), K_{\mathrm{d}}(380)$, $K_{\mathrm{d}}(395)$ and $K_{\mathrm{d}}(\mathrm{PAR})$ are $5.04 \pm 4.52 \mathrm{~m}^{-1}, 4.67 \pm 4.66 \mathrm{~m}^{-1}$, $4.48 \pm 4.63 \mathrm{~m}^{-1}, 3.65 \pm 4.10 \mathrm{~m}^{-1}, 2.47 \pm 3.00 \mathrm{~m}^{-1}, 2.40 \pm 2.94$ $\mathrm{m}^{-1}$ and $0.98 \pm 0.94 \mathrm{~m}^{-1}$, respectively. For further analyses, the UV-B at $313 \mathrm{~nm}$ and the UV-A at $380 \mathrm{~nm}$ were chosen to represent UVR in the following sections. In terms of $K_{\mathrm{d}}(\mathrm{UV}-\mathrm{B})$, the average values of $\mathrm{LCH}, \mathrm{LDC}, \mathrm{LEH}, \mathrm{LFX}$, LLG and LYZ are $3.59 \pm 0.47 \mathrm{~m}^{-1}, 13.30 \pm 1.96 \mathrm{~m}^{-1}$, $5.21 \pm 0.45 \mathrm{~m}^{-1}, \quad 1.03 \pm 0.13 \mathrm{~m}^{-1}, \quad 0.59 \pm 0.09 \mathrm{~m}^{-1}$ and $2.90 \pm 0.28 \mathrm{~m}^{-1}$, respectively (Fig. 1) and differed significantly among the lakes $(\mathrm{P}<0.01)$. For $K_{\mathrm{d}}(\mathrm{UV}-\mathrm{A})$, the average values of $\mathrm{LCH}, \mathrm{LDC}, \mathrm{LEH}, \mathrm{LFX}, \mathrm{LLG}$ and LYZ are $1.49 \pm 0.28 \mathrm{~m}^{-1}, 8.00 \pm 2.13 \mathrm{~m}^{-1}, 2.28 \pm 0.45 \mathrm{~m}^{-1}$, $0.43 \pm 0.12 \mathrm{~m}^{-1}, 0.26 \pm 0.08 \mathrm{~m}^{-1}$ and $1.36 \pm 0.20 \mathrm{~m}^{-1}$, respectively (Fig. 1), and also significantly differed among the lakes $(\mathrm{P}<0.01)$. Finally, with respect to $K_{\mathrm{d}}(\mathrm{PAR})$, the average values of LCH, LDC, LEH, LFX, LLG and LYZ are $0.77 \pm 0.13 \mathrm{~m}^{-1}, \quad 2.72 \pm 0.65 \mathrm{~m}^{-1}, 0.78 \pm 0.17 \mathrm{~m}^{-1}$, $0.34 \pm 0.13 \mathrm{~m}^{-1}, 0.25 \pm 0.08 \mathrm{~m}^{-1}$ and $0.74 \pm 0.16 \mathrm{~m}^{-1}$, respectively (Fig. 1); no significant differences are observed among three mesotrophic lakes LCH, LEH and LYZ ( $P=$ $0.384)$. The $K_{\mathrm{d}}(\mathrm{PAR})$ value of LDC is significantly higher than the $K_{\mathrm{d}}(\mathrm{PAR})$ values of $\mathrm{LCH}, \mathrm{LEH}$ and LYZ $(\mathrm{P}<0.01)$, which are significantly higher than the $K_{\mathrm{d}}(\mathrm{PAR})$ value of LFX $(\mathrm{P}<0.01)$. Furthermore, the $K_{\mathrm{d}}(\mathrm{PAR})$ of LFX is significantly higher than that of LLG $(\mathrm{P}<0.01)$.

Regarding seasonal changes, an analysis incorporating all six lakes reveals no significant seasonal variations in $K_{\mathrm{d}}(\mathrm{UV}-\mathrm{B}), K_{\mathrm{d}}(\mathrm{UV}-\mathrm{A})$ and $K_{\mathrm{d}}(\mathrm{PAR})(\mathrm{P}>0.05)$. However, the independent analysis of each lake demonstrates that the $\mathrm{K}_{d}(\mathrm{UV}-\mathrm{B}), \mathrm{K}_{d}(\mathrm{UV}-\mathrm{A})$ and $\mathrm{K}_{d}(\mathrm{PAR})$ values of $\mathrm{LCH}$, LDC, LEH and LYZ are all significantly different across seasons $(\mathrm{P}<0.01)$. In $\mathrm{LFX}, \mathrm{K}_{\mathrm{d}}(\mathrm{UV}-\mathrm{B})$ and $\mathrm{K}_{\mathrm{d}}(\mathrm{UV}-\mathrm{A})$ have significant seasonal differences $(\mathrm{P}<0.01)$, whereas $\mathrm{K}_{\mathrm{d}}(\mathrm{PAR})$ is not significantly different across seasons $(\mathrm{P}>0.05)$. The $\mathrm{K}_{\mathrm{d}}(\mathrm{UV}-\mathrm{B}), \mathrm{K}_{\mathrm{d}}(\mathrm{UV}-\mathrm{A})$ and $\mathrm{K}_{\mathrm{d}}(\mathrm{PAR})$ values of LLG are not significantly different across seasons 
$(\mathrm{P}>0.05)$. The two-way analysis of variance comparing the six lakes and the four seasons indicates that the lake and its interaction with the season significantly contribute to the variations of $\operatorname{Ln}\left(K_{\mathrm{d}}(313)\right), \operatorname{Ln}\left(K_{\mathrm{d}}(380)\right)$ and $\operatorname{Ln}\left(K_{\mathrm{d}}(\mathrm{PAR})\right)$, but the season is not (Tab. 2).

\section{Variations in CDOM absorptions and the contents of Chl $a$ and TSS}

As shown in Fig. 2, the CDOM absorptions are greatly different among the six lakes and seem to be different among the four seasons in each lake; the average values of $a_{\mathrm{g}}(254)$ of LCH, LDC, LEH, LFX, LLG and LYZ are $15.22 \pm 0.53 \mathrm{~m}^{-1}, \quad 20.08 \pm 1.37 \mathrm{~m}^{-1}, \quad 13.44 \pm 0.72 \mathrm{~m}^{-1}$, $3.64 \pm 0.65 \mathrm{~m}^{-1}, 2.68 \pm 0.77 \mathrm{~m}^{-1}$ and $8.80 \pm 0.64 \mathrm{~m}^{-1}$, respectively. The average $\mathrm{Chl} a$ concentrations of LCH, LDC, LEH, LFX, LLG and LYZ are 11.36 $\pm 7.81 \mu \mathrm{g} / \mathrm{L}, 39.60 \pm$
$19.10 \mu \mathrm{g} / \mathrm{L}, 7.52 \pm 4.34 \mu \mathrm{g} / \mathrm{L}, 1.56 \pm 0.62 \mu \mathrm{g} / \mathrm{L}, 0.15 \pm 0.17$ $\mu \mathrm{g} / \mathrm{L}$ and $24.23 \pm 13.54 \mu \mathrm{g} / \mathrm{L}$, respectively (Tab. 1 and Fig. 3). Regarding the TSS concentrations (Fig. 4), the average values of LCH, LDC, LEH, LFX, LLG and LYZ are $7.46 \pm 6.21 \mathrm{mg} / \mathrm{L}, 38.15 \pm 22.31 \mathrm{mg} / \mathrm{L}, 5.14 \pm 2.85 \mathrm{mg} / \mathrm{L}$, $1.24 \pm 0.54 \mathrm{mg} / \mathrm{L}, 0.64 \pm 0.55 \mathrm{mg} / \mathrm{L}$ and $17.03 \pm 13.92 \mathrm{mg} / \mathrm{L}$, respectively. The values of $a_{\mathrm{g}}(254), \mathrm{Chl} a$ and TSS are all significantly different among the lakes $(\mathrm{P}<0.01)$. In terms of seasonal change, the analysis incorporating all six lakes shows no significant seasonal differences in $\mathrm{a}_{\mathrm{g}}(254)$, Chl $a$ and TSS ( $\mathrm{P}>0.05)$; nevertheless, separate analyses of each lake suggest that all six lakes have significant seasonal differences in these three OASs $(\mathrm{P}<0.01)$. In spite of these, the lake (dominant one), the season and their interaction all have significant contributions to the variations of the three OASs (Tab. 2).

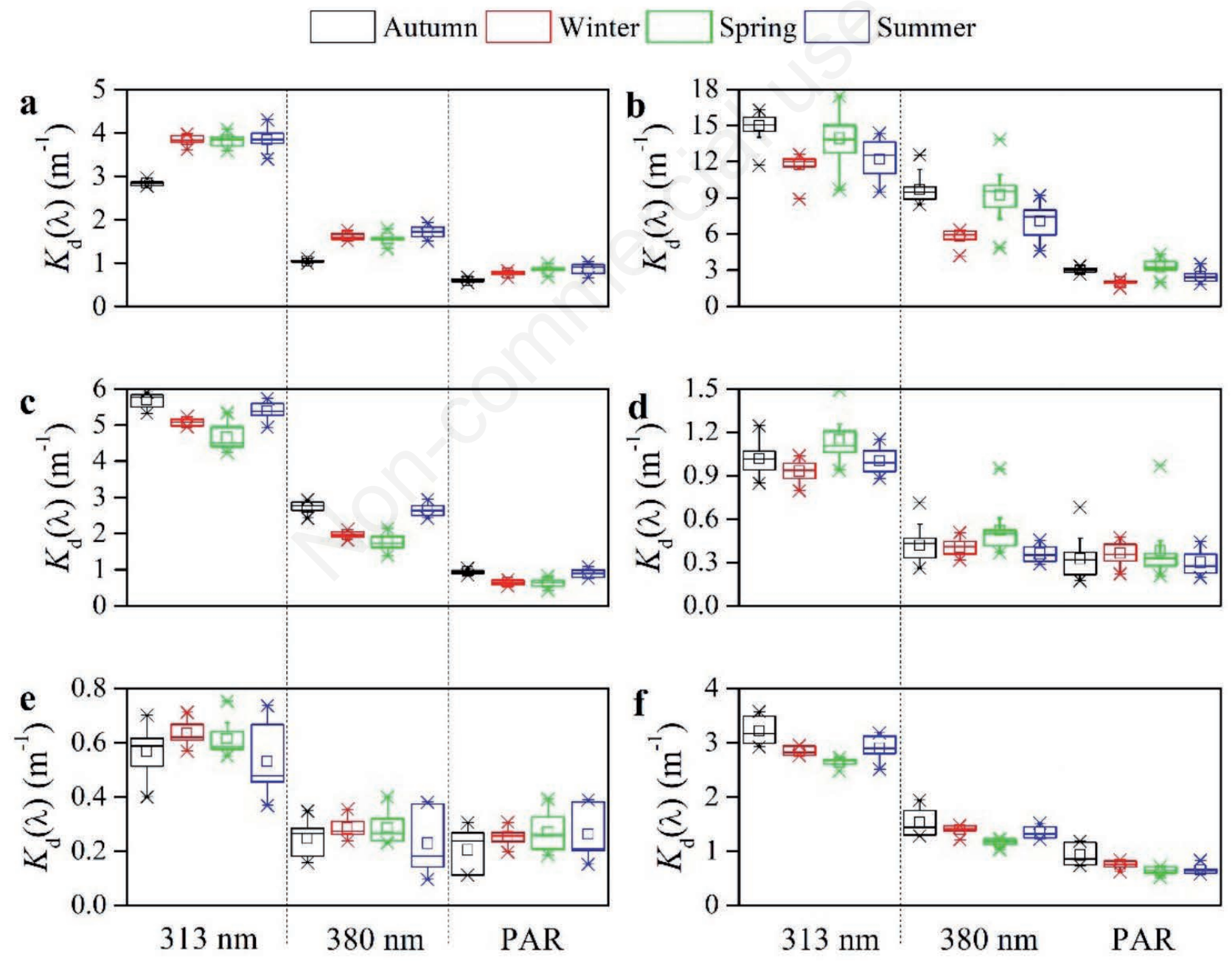

Fig. 1. Seasonal variations in the diffuse attenuation coefficients of UV-B (313 nm), UV-A (380 nm) and PAR (400-700 nm) in Lake Chenghai (a), Lake Dianchi (b), Lake Erhai (c), Lake Fuxian (d), Lake Lugu (e) and Lake Yangzong (f). The upper and lower borders and the internal horizontal line of each box represent upper quartile, lower quartile and median, respectively; "-" represents minimum and maximum values, “×” represents $1 \%$ and $99 \%$ values, “ $\square$ " represents mean value. 
Relationships between $K_{d}(\lambda)$ and the three OASs

To determine the correlation between $K_{\mathrm{d}}(\lambda)$ and the content of the main OAS that affects $K_{\mathrm{d}}(\lambda)$, a Spearman correlation analysis was performed between $K_{\mathrm{d}}(\lambda)$ and $a_{\mathrm{g}}(254), \mathrm{Chl} a$ and TSS. In general, $K_{\mathrm{d}}(\mathrm{UV}-\mathrm{B}), K_{\mathrm{d}}(\mathrm{UV}-$ A) and $K_{d}(\mathrm{PAR})$ are significantly positively correlated with $a_{\mathrm{g}}(254), \mathrm{Chl} a$ and TSS. However, the correlation

Tab. 2. Results of the two-way analysis of variance comparing the six lakes and the four seasons for $\operatorname{Ln}\left(K_{\mathrm{d}}(\lambda)\right), \operatorname{Ln}\left(a_{\mathrm{g}}(254)\right), \operatorname{Ln}(\operatorname{Chl} a)$ and $\operatorname{Ln}(\mathrm{TSS})$.

\begin{tabular}{|c|c|c|c|c|c|}
\hline \multirow[b]{2}{*}{ Parameter } & \multicolumn{5}{|c|}{$F$ value } \\
\hline & Lakes & Seasons & Interaction & $R_{\mathrm{adj}}^{2}$ & $\mathbf{N}$ \\
\hline $\operatorname{Ln}\left(K_{\mathrm{d}}(313)\right)$ & $5720.802^{* * *}$ & $1.475^{\mathrm{ns}}$ & $12.650^{* * *}$ & 0.992 & 249 \\
\hline $\operatorname{Ln}\left(K_{\mathrm{d}}(380)\right)$ & $1930.801^{* * *}$ & $1.345^{\mathrm{ns}}$ & $12.203^{* * *}$ & 0.976 & 248 \\
\hline $\operatorname{Ln}\left(K_{\mathrm{d}}(\mathrm{PAR})\right)$ & $639.099^{* * *}$ & $1.131^{\mathrm{ns}}$ & $6.886^{* * *}$ & 0.931 & 248 \\
\hline $\operatorname{Ln}\left(a_{\mathrm{g}}(254)\right)$ & $3221.486^{* * *}$ & $28.456^{* * *}$ & $12.160^{* * *}$ & 0.985 & 250 \\
\hline $\operatorname{Ln}(\mathrm{Chl} a)$ & $1655.674^{* * * *}$ & $33.798^{* * *}$ & $24.459^{* * *}$ & 0.972 & 256 \\
\hline $\operatorname{Ln}(\mathrm{TSS})$ & $765.206^{* * *}$ & $7.401^{* * *}$ & $26.610^{* * *}$ & 0.943 & 256 \\
\hline
\end{tabular}

Lakes, $d f=5$; Seasons, $d f=3$; interaction, $d f=15$ exception for $\operatorname{Ln}\left(a_{g}(254)\right)$ that $d f=14$. $* * * P<0.001$; ns, no significance $(P>0.05)$.
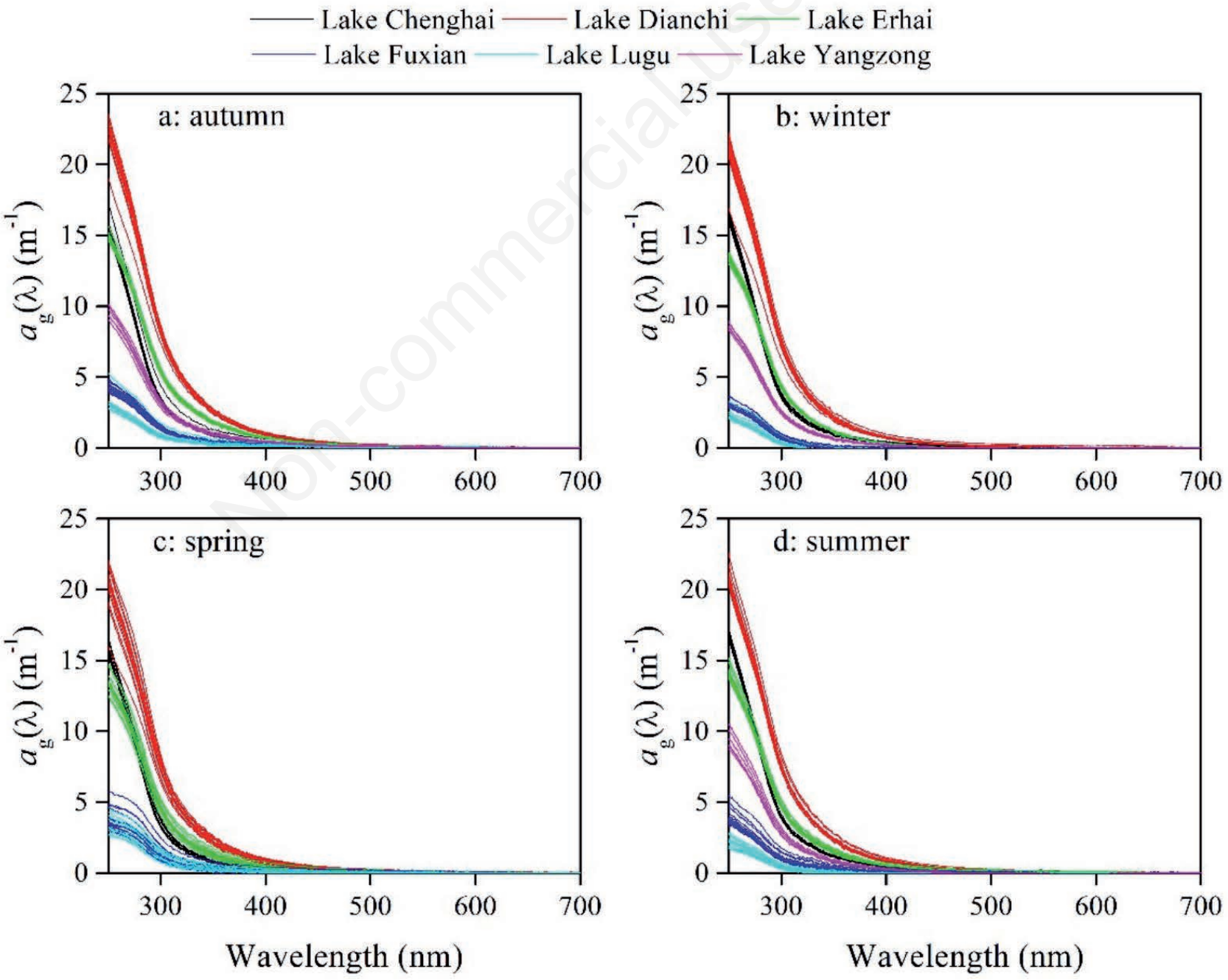

Fig. 2. Seasonal absorption spectra $(250-700 \mathrm{~nm})$ of chromophoric dissolved organic matter (CDOM) in the six lakes (no data of Lake Yangzong in spring). 
analysis results for different seasons exhibit no evident discrepancies, while those for different lakes vary greatly (Tab. 3). Moreover, a stepwise regression analysis between $\operatorname{Ln}\left(K_{d}(\lambda)\right)$ and the three OASs was performed to further compare the main influential factors of $K_{\mathrm{d}}(\lambda)$ among the six lakes. In LCH, $K_{\mathrm{d}}(\mathrm{UV}-\mathrm{B}), K_{\mathrm{d}}(\mathrm{UV}-\mathrm{A})$ and $K_{\mathrm{d}}(\mathrm{PAR})$ are all significantly positively correlated with $a_{\mathrm{g}}$ (254), Chl $a$ and TSS (Tab. 3); CDOM and TSS are the main factors for $K_{\mathrm{d}}(\mathrm{UVR}), \mathrm{CDOM}$ is the main factor for $K_{\mathrm{d}}(\mathrm{PAR})$ (Tab. 4). In LDC, $K_{\mathrm{d}}(\mathrm{UV}-\mathrm{B}), K_{\mathrm{d}}(\mathrm{UV}-\mathrm{A})$ and $K_{\mathrm{d}}(\mathrm{PAR})$ are all significantly positively correlated with Chl $a$ and TSS, but $a_{\mathrm{g}}(254)$ is significantly positively correlated only with $K_{\mathrm{d}}(\mathrm{UV}-\mathrm{B})$ (Tab. 3$)$; CDOM and TSS are the main factors for $K_{\mathrm{d}}(\mathrm{UV}-\mathrm{B})$, while TSS and phytoplankton are the main factors for $K_{\mathrm{d}}(\mathrm{UV}-\mathrm{A})$ and $K_{\mathrm{d}}(\mathrm{PAR})$, respectively (Tab. 4). In LEH, except for between $K_{\mathrm{d}}(\mathrm{UV}-\mathrm{B})$ and TSS, there are significant positive correlations among $K_{\mathrm{d}}(\mathrm{UV}-\mathrm{B}), K_{\mathrm{d}}(\mathrm{UV}-\mathrm{A})$ and $K_{\mathrm{d}}(\mathrm{PAR})$ and $a_{\mathrm{g}}(254)$, Chl $a$ and TSS (Tab. 3); CDOM is the main factor for $K_{\mathrm{d}}(\mathrm{UVR})$ and $K_{\mathrm{d}}(\mathrm{PAR})$, while phytoplankton is also the main factor for $K_{\mathrm{d}}(\mathrm{UV}-\mathrm{A})$ and $K_{\mathrm{d}}(\mathrm{PAR})$ (Tab. 4). The analysis of LFX shows a significant positive correlation only between $a_{\mathrm{g}}(254)$ and $K_{\mathrm{d}}(\mathrm{UV}-\mathrm{B})$, whereas that of LGH shows a significant correlation (negative) only between TSS and $K_{d}$ (PAR) (Tab. 3); however, the stepwise regression indicates that $\mathrm{CDOM}$ also has an effect on $K_{\mathrm{d}}(\mathrm{UV}-\mathrm{A}$ ) in LFX (Tab. 4). For LYZ, there is a significant correlation only between $K_{\mathrm{d}}(\mathrm{UV}-\mathrm{A})$ and $\mathrm{Chl} a$; a weak correlation is found between $K_{\mathrm{d}}(\mathrm{UV}-\mathrm{B})$ and $a_{\mathrm{g}}(254)$ $(\mathrm{P}=0.076)$ (Tab. 3), but no significant regression is detected (Tab. 4). According to an analysis incorporating all the samples, CDOM and phytoplankton are the two main influential factors for each $K_{\mathrm{d}}(\lambda)$ (Tab. 4), where the standardized beta coefficients of $a_{\mathrm{g}}(254)$ and Chl $a$ are 0.893 and 0.104 for $K_{\mathrm{d}}(\mathrm{UV}-\mathrm{B}), 0.820$ and 0.189 for $K_{\mathrm{d}}(\mathrm{UV}-\mathrm{A})$, 0.717 and 0.290 for $K_{\mathrm{d}}(\mathrm{PAR})$, respectively; specially, this
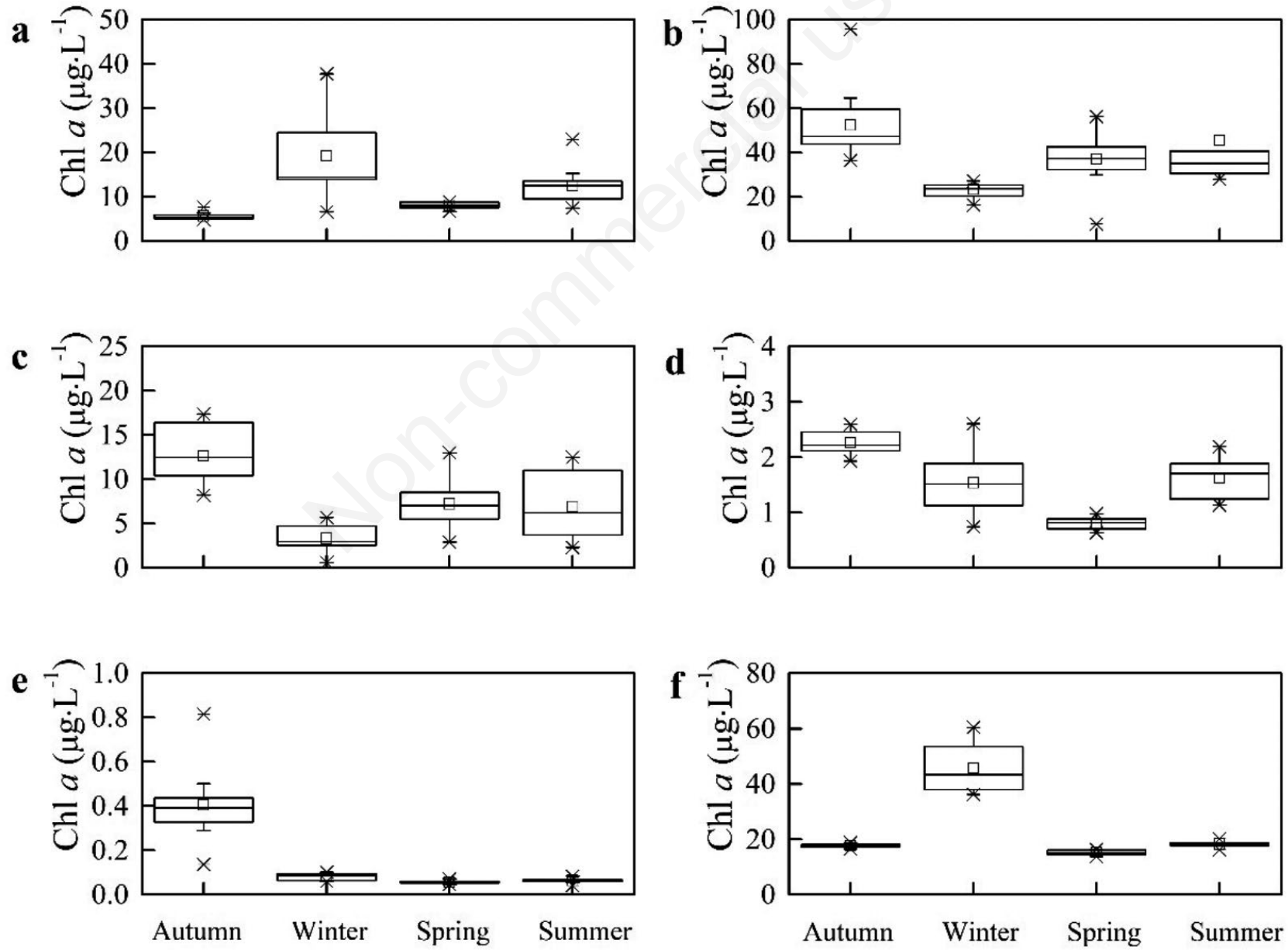

Fig. 3. Seasonal variations in chlorophyll $a(\mathrm{Chl} a)$ concentrations in Lake Chenghai (a), Lake Dianchi (b), Lake Erhai (c), Lake Fuxian (d), Lake Lugu (e) and Lake Yangzong (f). The upper and lower borders and the internal horizontal line of each box represent upper quartile, lower quartile and median, respectively; "-_" represents minimum and maximum values, " $\times$ " represents $1 \%$ and $99 \%$ values, " 口" represents mean value. 
trend of the standardized beta coefficients is the same as the regression result for each season. Additionally, $K_{\mathrm{d}}(\mathrm{UV}$ B), $K_{\mathrm{d}}(\mathrm{UV}-\mathrm{A})$ and $K_{\mathrm{d}}(\mathrm{PAR})$ all exponentially increase with the trophic state represented by $T L I_{\mathrm{C} 4}$; it seems that the $K_{\mathrm{d}}(\lambda)$ does not increase significantly with the $T L I_{\mathrm{C} 4}$ among the three mesotrophic lakes (Fig. 5).

Tab. 3. Spearman correlations between $K_{\mathrm{d}}(\lambda)$ and the three optically active substances.

\begin{tabular}{|c|c|c|c|c|c|c|c|c|c|c|c|c|}
\hline \multirow[t]{2}{*}{$K_{d}(\lambda)$} & \multirow[t]{2}{*}{ Parameter } & \multirow[t]{2}{*}{ Total } & \multicolumn{6}{|c|}{ Lake } & \multicolumn{4}{|c|}{ Season } \\
\hline & & & LCH & LDC & LEH & LFX & LLG & LYZ & Autumn & Winter & Spring & Summer \\
\hline \multirow[t]{3}{*}{$K_{\mathrm{d}}(313)$} & $a_{\mathrm{g}}(254)$ & $0.909^{* *}$ & $0.448^{* *}$ & $0.398^{* *}$ & $0.637^{* *}$ & $0.473^{* *}$ & -0.128 & 0.428 & $0.885^{* *}$ & $0.910^{* *}$ & $0.863^{* *}$ & $0.921^{* *}$ \\
\hline & Chl $a$ & $0.841^{* *}$ & $0.660^{* *}$ & $0.460^{* *}$ & $0.492^{* *}$ & -0.218 & -0.056 & 0.290 & $0.937^{* *}$ & $0.677^{* *}$ & $0.844^{* *}$ & $0.843^{* *}$ \\
\hline & TSS & $0.835^{* *}$ & $0.704^{* *}$ & $0.486^{* *}$ & 0.260 & -0.116 & -0.143 & -0.273 & $0.886^{* *}$ & $0.684^{* *}$ & $0.837^{* *}$ & $0.842^{* *}$ \\
\hline \multirow[t]{3}{*}{$K_{\mathrm{d}}(380)$} & $a_{\mathrm{g}}(254)$ & $0.895^{* *}$ & $0.617^{* *}$ & 0.226 & $0.610^{* *}$ & 0.208 & -0.067 & 0.086 & $0.867^{* *}$ & $0.907^{* *}$ & $0.870^{* *}$ & $0.901^{* *}$ \\
\hline & Chl $a$ & $0.846^{* *}$ & $0.669^{* *}$ & $0.551^{* *}$ & $0.516^{* *}$ & -0.172 & -0.132 & $0.542^{* *}$ & $0.943^{* *}$ & $0.676^{* *}$ & $0.850^{* *}$ & $0.825^{* *}$ \\
\hline & TSS & $0.840^{* *}$ & $0.658^{* *}$ & $0.513^{* *}$ & $0.328^{*}$ & -0.115 & -0.200 & -0.071 & $0.894^{* *}$ & $0.681^{* *}$ & $0.844^{* *}$ & $0.821^{* *}$ \\
\hline \multirow[t]{3}{*}{$K_{\mathrm{d}}(\mathrm{PAR})$} & $a_{\mathrm{g}}(254)$ & $0.887^{* *}$ & $0.473^{* *}$ & 0.125 & $0.627^{* *}$ & 0.050 & -0.173 & 0.065 & $0.838^{* *}$ & $0.909^{* *}$ & $0.887^{* *}$ & $0.909^{* *}$ \\
\hline & Chl $a$ & $0.866^{* *}$ & $0.463^{* *}$ & $0.597^{* *}$ & $0.601^{* *}$ & -0.055 & -0.314 & 0.207 & $0.936^{* *}$ & $0.846^{* *}$ & $0.814^{* *}$ & $0.845^{* *}$ \\
\hline & TSS & $0.853^{* *}$ & $0.544^{* *}$ & $0.483^{* *}$ & $0.416^{* *}$ & 0.015 & $-0.390^{*}$ & -0.157 & $0.892^{* *}$ & $0.852^{* *}$ & $0.811^{* *}$ & $0.842^{* *}$ \\
\hline
\end{tabular}

$* P<0.05 ; * * P<0.01$.
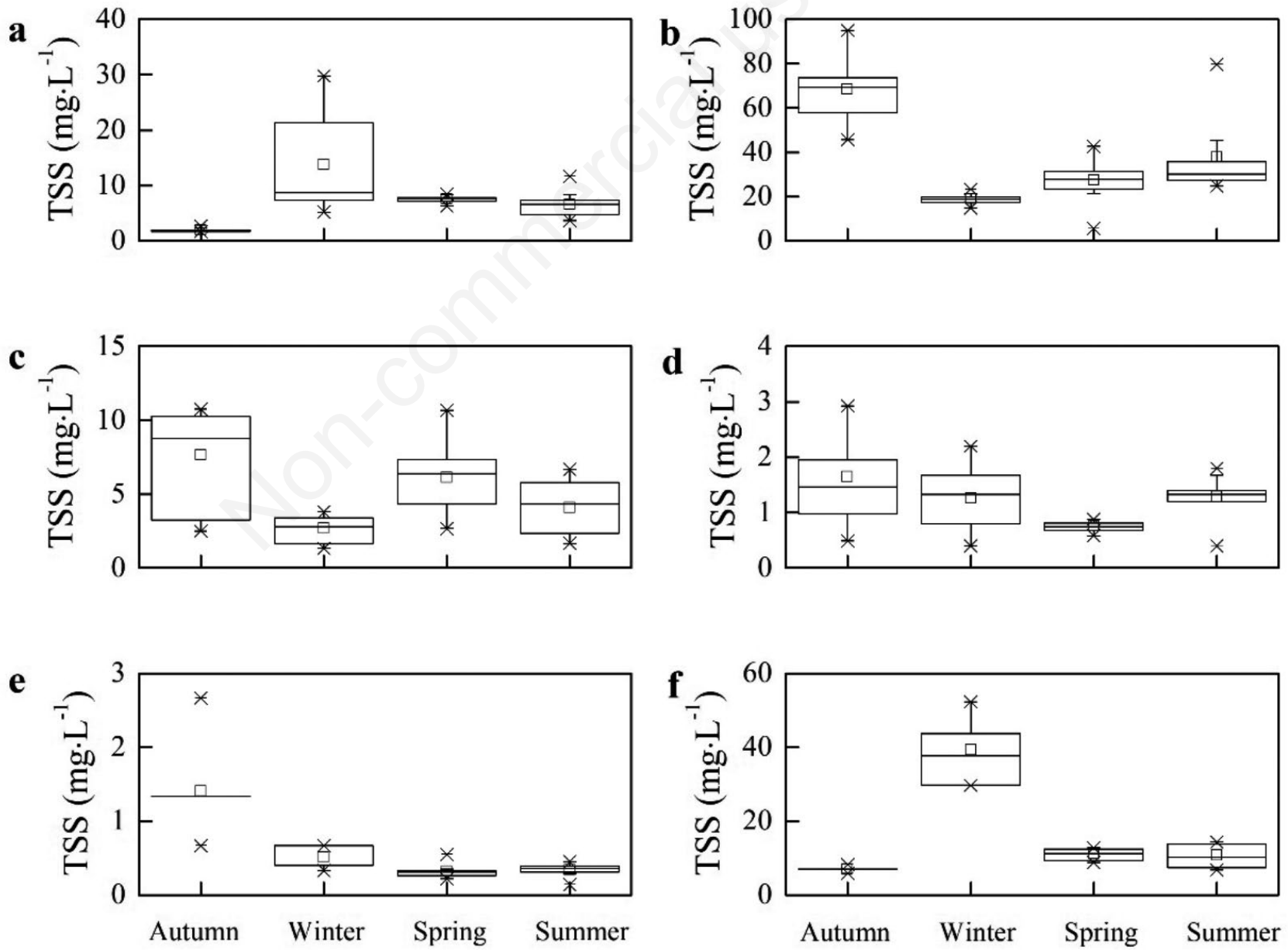

Fig. 4. Seasonal variations in the concentration of total suspended solids (TSS) in Lake Chenghai (a), Lake Dianchi (b), Lake Erhai (c), Lake Fuxian (d), Lake Lugu (e) and Lake Yangzong (f). The upper and lower borders and the internal horizontal line of each box represent upper quartile, lower quartile and median, respectively; “_” represents minimum and maximum values, "X" represents $1 \%$ and $99 \%$ values, “ $\square$ " represents mean value. 


\section{DISCUSSION}

The optical properties of alpine lakes, which are sentinels of environmental change because of their extreme sensitivity (Mladenov et al., 2009; Mladenov et al., 2011), typically differ from those of other lakes (Rose et al., 2009; Zhang et al., 2011) and experience significant shifts under changing environments (Laurion et al., 2000; Sommaruga and Augustin, 2006; Rose et al., 2009; Zhou et al., 2019), although alpine lakes are more autochthonous than subalpine lakes in general (Rose et al., 2015). There are many studies on water optical properties specifically
$K_{\mathrm{d}}(\lambda)$ of mountain lakes, e.g., Alps lakes (Laurion et al., 2000; Sommaruga and Augustin, 2006), Andes lakes (Pérez et al., 2002; Aguilera et al., 2013) and other lakes across continents (Rose et al., 2009; 2014; 2015), but the in situ data of $K_{\mathrm{d}}(\lambda)$ in lakes of the Yunnan Plateau are scarce (Zhang et al., 2011; Zhou et al., 2018). In the present study, the seasonal values of $K_{\mathrm{d}}(\mathrm{UVR})$ and $K_{\mathrm{d}}(\mathrm{PAR})$ and their major (direct) influencing factors of the six typical Yunnan Plateau lakes are given, and the spectral, seasonal and interlake heterogeneities of them are further compared.

Sunlight attenuation is characterized by spectrum het-

Tab. 4. Stepwise regression between $\operatorname{Ln}\left(K_{\mathrm{d}}(\lambda)\right)$ and $a_{\mathrm{g}}(254)$, Chl $a$ and TSS.

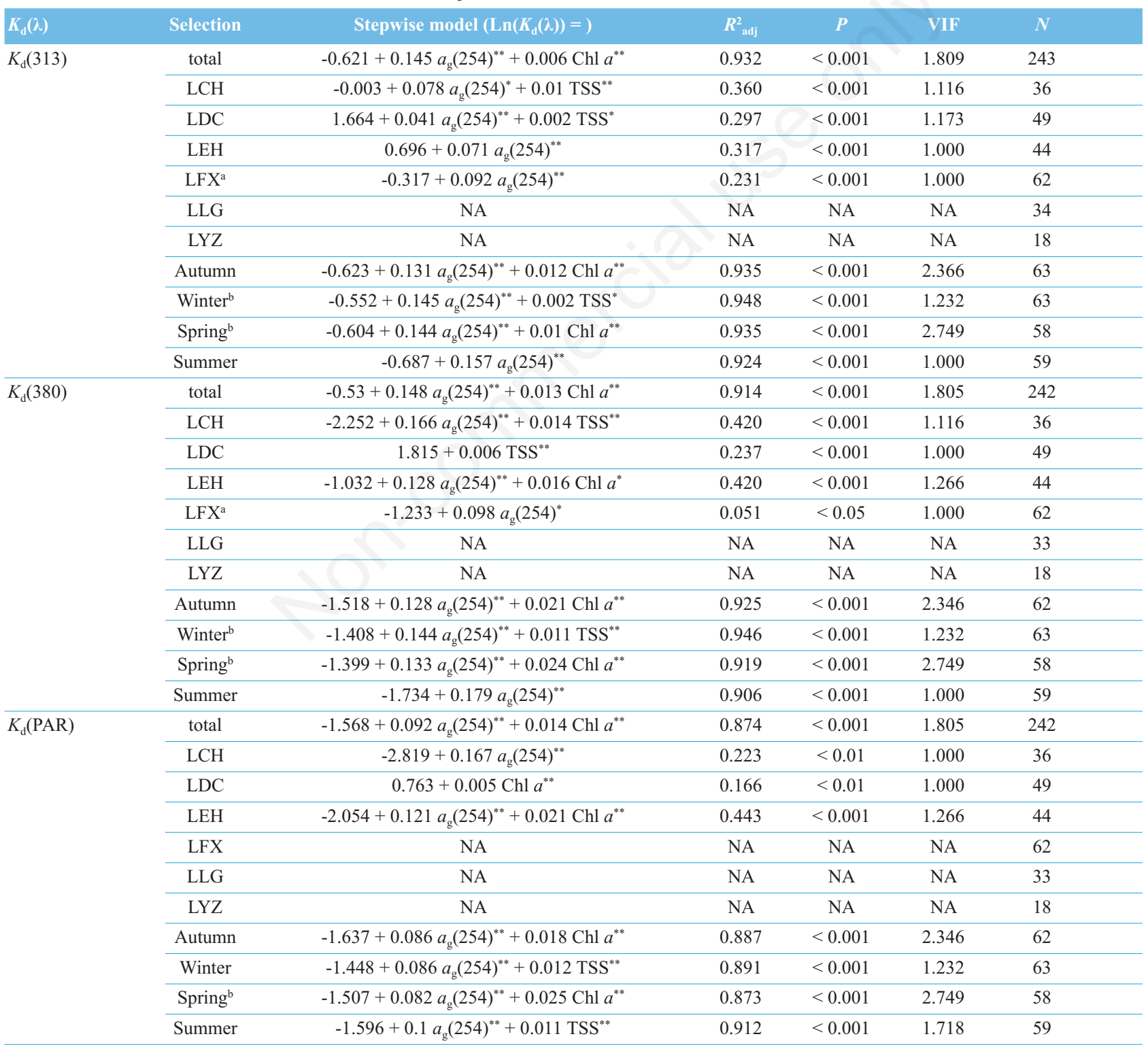

athe last model containing the two independent variables $\mathrm{a}_{\mathrm{g}}(254)$ and Chl a that with a negative beta is not shown; ${ }^{b}$ the last model with a great collinearity between Chl a and TSS is not shown, even though their $\mathrm{R}^{2}$ adj is slightly larger than the current one. Significance of independent variables: $*$ P $<.05$; $* * P<0.01$ 
erogeneity, interlake heterogeneity and seasonal heterogeneity within one lake. In this study, $K_{\mathrm{d}}(\lambda)$ declines with increasing wavelength, which is consistent with previous studies (De Lange, 2000; Zhang et al., 2011; Rose et al., 2014; Forsström et al., 2015). Moreover, many studies regarding regional or interlake heterogeneity of $K_{\mathrm{d}}(\lambda)$ have been published (De Lange, 2000; Zhang et al., 2011; Aguilera et al., 2013; Rose et al., 2014; Forsström et al., 2015). For example, with the same solar spectrum, mesotrophic LEH and Lake Litang both have higher $K_{\mathrm{d}}(320)$ and $K_{\mathrm{d}}(360)$ values than oligotrophic LFX, and the $K_{\mathrm{d}}(320)$ and $K_{\mathrm{d}}(360)$ values of eutrophic Lake Dong exceed those of mesotrophic Lake Tianmu and Lake Liangzi (Zhang et al., 2011). We hypothesize that the differences in the observed $K_{\mathrm{d}}(\lambda)$ are due to the different contents of dissolved and particulate OASs and the sizes of their relative contribution. For example, the $K_{\mathrm{d}}(\lambda)$ of the shallow LDC is greater than that of the other lakes, which is explained by the highest contents of CDOM and TSS that contains phytoplankton in LDC. $K_{\mathrm{d}}(\mathrm{UV}-\mathrm{B}), K_{\mathrm{d}}(\mathrm{UV}-$ A) and $K_{\mathrm{d}}(\mathrm{PAR})$ all exponentially increase with increasing trophic state, but no significant differences of $K_{\mathrm{d}}(\mathrm{PAR})$ are found among the three mesotrophic lakes in the present study. This result indicates that $K_{\mathrm{d}}(\mathrm{UVR})$ has a greater interlake heterogeneity than $K_{\mathrm{d}}(\mathrm{PAR})$; similarly, the contribution of interlake heterogeneity to $K_{\mathrm{d}}(\lambda)$ may decrease with increasing wavelength (Tab. 2). However, $K_{\mathrm{d}}(\lambda)$ does not increase exponentially with increasing trophic state in the mesotrophic lakes (Fig. 5), which may be explained by that NAPs do not necessarily increase with increasing trophic state, and that a lot of Fe(III) (LYZ) may strongly increase lake water absorption (Baffico, 2013).

With respect to seasonal changes, $K_{\mathrm{d}}(\mathrm{PAR})$ is signifi- cantly higher in spring and summer than in autumn and winter in the shallow, hypereutrophic turbid lake Laguna Chascomús (Pérez et al., 2011). The $K_{\mathrm{d}}(\mathrm{UV}-\mathrm{B}), K_{\mathrm{d}}(\mathrm{UV}$ A) and $K_{\mathrm{d}}(\mathrm{PAR})$ values of the deep oligotrophic Lake Dom Helvécio are significantly higher in the dry season than in the rainy season, whereas the eutrophic Reservoir Pampulha exhibits the opposite trend (Brandão et al., 2016). In the present study, the analysis combining all six lakes shows no seasonal heterogeneity of $K_{\mathrm{d}}(\mathrm{UV}-\mathrm{B})$, $K_{\mathrm{d}}(\mathrm{UV}-\mathrm{A})$ and $K_{\mathrm{d}}(\mathrm{PAR})$, which means that the interlake heterogeneity surpasses the seasonal heterogeneity of $K_{\mathrm{d}}(\lambda)$; this is also confirmed by the results of the two-way analysis of variance, although the change of seasons may significantly contribute to the variations of OASs (the contribution of the season is lower than that of the lake) (Tab. 2). However, the seasonal heterogeneity is evident within each lake and is related to the solar spectrum and the lake trophic state. For example, in eutrophic LDC and the three mesotrophic lakes (LCH, LEH and LYZ), all three $K_{\mathrm{d}}(\lambda)$ parameters are seasonally heterogenous. However, in oligotrophic clear LFX, only $K_{\mathrm{d}}(\mathrm{UV}-\mathrm{B})$ and $K_{\mathrm{d}}(\mathrm{UV}-\mathrm{A})$ demonstrate seasonal heterogeneity; moreover, in more oligotrophic and clearer LLG, $K_{\mathrm{d}}(\mathrm{UV}-\mathrm{B}), K_{\mathrm{d}}(\mathrm{UV}-$ A) and $K_{\mathrm{d}}(\mathrm{PAR})$ show no seasonal heterogeneity. This result indicates that the intralake seasonal heterogeneity of $K_{\mathrm{d}}(\lambda)$ may increase with decreasing wavelength and increasing trophic state.

Due to differences in the content and composition of OASs, the major factors affecting $K_{\mathrm{d}}(\lambda)$ are subjected to regional heterogeneity. For example, pure water and organic matter are considered the main influential factors of $K_{\mathrm{d}}(\mathrm{PAR})$ in lakes in Tasmania (Bowling et al., 1986), the TSS is thought to be the decisive factor of $K_{\mathrm{d}}(\mathrm{PAR})$

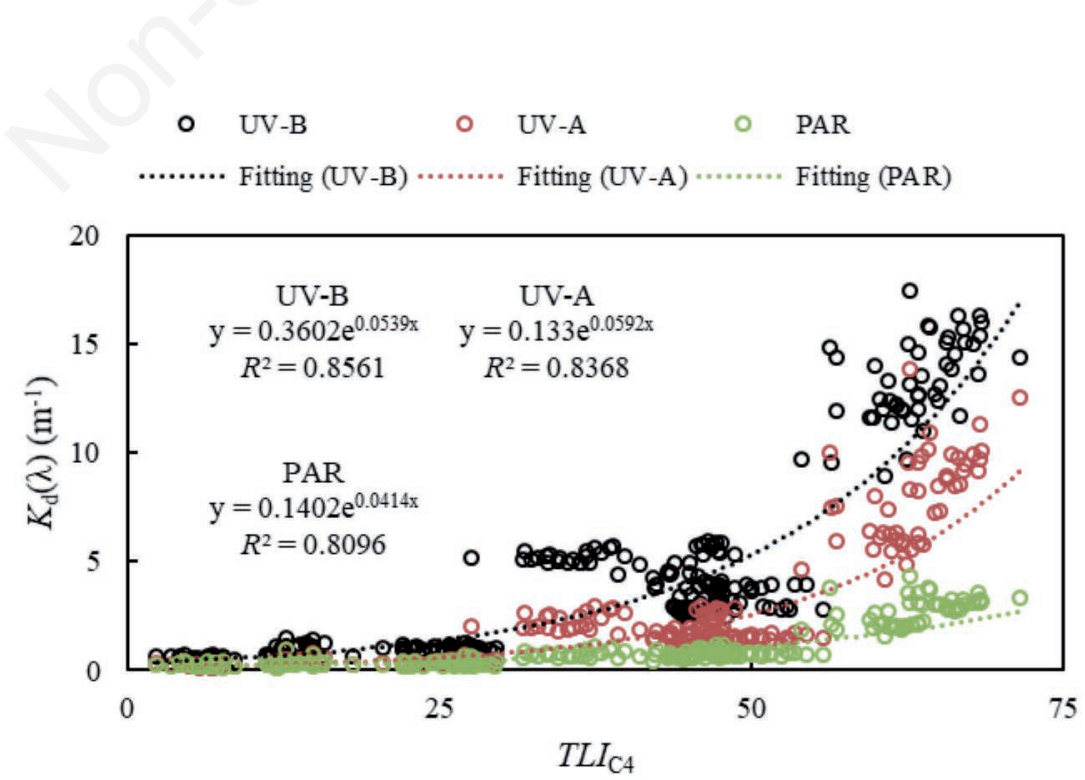

Fig. 5. Relationships of the diffuse attenuation coefficients $\left(K_{d}(\lambda)\right)$ for UV-B (313 nm, black), UV-A ( $380 \mathrm{~nm}$, red) and PAR (400-700 $\mathrm{nm}$, green) with the trophic state $\left(T L I_{\mathrm{C} 4}\right)$. 
for lakes in northeastern China (Ma et al., 2016), but the variability of $K_{\mathrm{d}}(\mathrm{PAR})$ among 16 shallow lakes of Argentina could be explained as much as $92 \%$ by CDOM and nephelometric turbidity (Pérez et al., 2010). Surveys of 42 stations of 16 lakes on the Yunnan-Guizhou Plateau in 2006 and 2007 indicate that CDOM, rather than tripton or phytoplankton, has the most important effect on $K_{\mathrm{d}}(\mathrm{UVR})$, even though all three OASs have great impacts on $K_{\mathrm{d}}(\mathrm{PAR})$ (Zhang et al., 2011). In the present study, the correlation analysis combining all six lakes and seasonal analysis shows that CDOM, phytoplankton and TSS are important influential factors for $K_{\mathrm{d}}(\mathrm{UV}-\mathrm{B}), K_{\mathrm{d}}(\mathrm{UV}-\mathrm{A})$ and $K_{\mathrm{d}}(\mathrm{PAR})$, which is mainly attributed to the interlake heterogeneity of the contents of OASs, this finding is similar to that of a previous study (Zhang et al., 2011). It is notable that the main influential factors for each $K_{\mathrm{d}}(\lambda)$ are CDOM and phytoplankton based on the stepwise regression analysis combining all the samples (Tab. 4), unlike the findings of Zhang et al. (2011), which may be explained by the varied selection of lakes and the increased number of samples. Laurion et al. (2000) indicated that the variability of $K_{\mathrm{d}}(\mathrm{UVR})$ among 26 clear mountain lakes in Alps and Pyrenees is controlled by CDOM rather than phytoplankton, that contributed significantly to the within-lake variation of $K_{\mathrm{d}}(\mathrm{UVR})$ in deeper waters with low dissolved organic carbon. This is different from our results, which may be explained by the greater interlake heterogeneity of Chl $a$ concentration among the six YP lakes with different trophic states. Additionally, the results of both the correlation combining all the samples and the regression analyses (the "total" and the seasonal analyses) imply that the effect of CDOM on $K_{\mathrm{d}}(\lambda)$ decrease with increasing wavelength due to its absorption property (Fig. $2)$, but the effect of phytoplankton on $K_{\mathrm{d}}(\mathrm{PAR})$ is greater than that on $K_{\mathrm{d}}(\mathrm{UVR})$, this is similar to the previous results (Zhang et al., 2011; Rose et al., 2014). Seasonally, dissolved and particulate OASs are also the main factors for each $K_{\mathrm{d}}(\lambda)$ in general (Tab. 4), this result combining with the seasonal results of the correlation analysis implies that more sampled lakes are needed to detect the seasonal changes of the main influential factors of $K_{\mathrm{d}}(\lambda)$, because of larger effect of interlake than interseason on the $K_{\mathrm{d}}(\lambda)$ values and the OASs currently.

For the different lakes, the effects of the OASs on $K_{\mathrm{d}}(\lambda)$ are also heterogenous. In shallow, eutrophic turbid LDC, the effects of CDOM on $K_{\mathrm{d}}(\lambda)$ are mostly limited to shorter-wavelength UV-B, whereas TSS (contains phytoplankton and NAPs) greatly impact $K_{\mathrm{d}}(\mathrm{UV}-\mathrm{B}), K_{\mathrm{d}}(\mathrm{UV}-$ A) and $K_{\mathrm{d}}(\mathrm{PAR})$. Moreover, for deep mesotrophic LCH and LEH, the three OASs exhibit influences on $K_{\mathrm{d}}(\mathrm{UV}$ B), $K_{\mathrm{d}}(\mathrm{UV}-\mathrm{A})$ and $K_{\mathrm{d}}(\mathrm{PAR})$, although the TSS has no evident influence on $K_{\mathrm{d}}(\mathrm{UV}-\mathrm{B})$ in LEH. Nonetheless, in deep, oligotrophic clear LFX and LLG, only CDOM has a positive significant effect on $K_{\mathrm{d}}(\mathrm{UV}-\mathrm{B})$ and a weaker significant effect on $K_{\mathrm{d}}(\mathrm{UV}-\mathrm{A})$ in LFX (Tab. 3 and Tab. 4), suggesting that low dissolved and particulate substances make the penetration of sunlight deeper resulting in a low $K_{d}(\lambda)$ value, especially for larger wavelengths in these clear lakes. Notably, since massive amounts of ferric chloride were added into LYZ from 2009 to 2011 ( $>6000$ t), the influential factors of $K_{\mathrm{d}}(\lambda)$ in LYZ differ greatly from those in LCH and LEH, even though all three lakes are deep mesotrophic lakes. These results imply that the number of effective OASs on $K_{\mathrm{d}}(\lambda)$ is highest in deep mesotrophic lakes, except for in the man-made, highly disturbed LYZ, which is similar to our previous study on water transparency based on long-term datasets of three YP lakes (i.e., LDC, LEH and LFX) (Zhou et al., 2019). Moreover, the main particulate factors affecting $K_{\mathrm{d}}(\lambda)$ are different when compared LCH to LEH, which may be related to different contribution of NAPs; these results combining with the comparison for the effects of CDOM between LFX and LLG, imply that the relative contribution of the main OASs affecting $K_{\mathrm{d}}(\lambda)$ may differ in lakes with approximate trophic states. Notably, the low $R_{\text {adj }}^{2}$ value of each stepwise regression in each lake indicates that there could be other important influential factors.

$K_{\mathrm{d}}(\lambda)$ is an important parameter for characterizing the apparent optical properties of water bodies. Its value directly reflects the penetration capacity of sunlight radiation through the water column, which directly affects the primary productivity and distribution of submerged macrophytes. There are several challenges facing YP lakes, such as climate change (Cheng et al., 2019; Li and Zha, 2019), variation in catchment land use (Xiao et al., 2018), lake surface warming (Yang et al., 2019), anthropogenic pollution (Ni et al., 2011) and even changes in meteorologically induced hydrological conditions; these challenges can impose significant effects on the input and/or photochemical process of OASs (Mladenov et al., 2009; Mladenov et al., 2011; Zhang et al., 2014; Zhou et al., 2019; Shi et al., 2020) and can profoundly affect $K_{\mathrm{d}}(\lambda)$ values and even lake ecosystems. Our previous study indicated that the main (direct and indirect) driving forces of the long-term trends of water transparency differ among three YP lakes (Zhou et al., 2019). A study of 18 high-latitude lakes demonstrated that the interlake heterogeneity of $K_{\mathrm{d}}(\lambda)$ and its most influential factor, DOM, are related to the catchment type (Forsström et al., 2015). Thus, the aforementioned driving factors and the interlake heterogeneity at the catchment perspective should be addressed in future research and lake management in the YP. For instance, the spatiotemporal heterogeneity of the major OASs affecting the intralake $K_{\mathrm{d}}(\lambda)$ needs to be analyzed in conjunction with catchment characteristics, water quality, meteorological and hydrological factors (e.g., solar radiation, rainfall) of each lake (Zhou et al., 2018). It is necessary to conduct further field investiga- 
tions that include tripton or NAPs concentrations and the absorptions of the four OASs for more comprehensive results. Additionally, we also suggest that the depth of measured underwater irradiance profiles in clear lakes should increase to improve the accuracy of $K_{\mathrm{d}}(\lambda)$ fitting results, especially for long wavelengths.

\section{CONCLUSIONS}

Seasonal $K_{\mathrm{d}}(\lambda)$ and its major direct influential factors of six typical lakes on the Yunnan Plateau are given and compared. $K_{\mathrm{d}}(\lambda)$ generally increases with decreasing wavelength and increasing trophic state, and compared with $K_{\mathrm{d}}(\mathrm{PAR}), K_{\mathrm{d}}(\mathrm{UVR})$ presents more evident heterogeneity among lakes. The interlake heterogeneity of $K_{\mathrm{d}}(\lambda)$ exceeds its seasonal heterogeneity, whereas seasonal heterogeneity occurs mainly within individual lakes and is related to the lake trophic state and solar spectrum. The effect of CDOM on $K_{\mathrm{d}}(\mathrm{UVR})$ is larger than $K_{\mathrm{d}}(\mathrm{PAR})$, the particulate substances exhibit the opposite trend in general, whereas the main factors affecting $K_{\mathrm{d}}(\lambda)$ are subjected to interlake heterogeneity. We recommend that further studies be established from the catchment perspective and with more complete datasets for lakes and OASs.

\section{ACKNOWLEDGMENTS}

The present work was jointly supported by the National Natural Science Foundation of China (No. 41601208), the National Key Research and Development Program of China (No. 2017YFA0605202) and the Basic Research Projects of Yunnan Province. We thank Yiliang Chen and Jufen Nie for their assistance with the field work and sample determination. We are grateful to the two anonymous reviewers for their constructive comments.

\section{REFERENCES}

Aguilera X, Lazzaro X, Coronel JS, 2013. Tropical high-altitude Andean lakes located above the tree line attenuate UV-A radiation more strongly than typical temperate alpine lakes. Photochem. Photobiol. Sci. 12:1649-1657.

Aparicio FL, Nieto-Cid M, Borrull E, Calvo E, Pelejero C, Sala MM, Pinhassi J, Gasol JM, Marrasé C, 2016. Eutrophication and acidification: do they induce changes in the dissolved organic matter dynamics in the coastal Mediterranean Sea? Sci. Total Environ. 563-564:179-189.

Baffico GD, 2013. Optical properties and light penetration in a deep, naturally acidic, iron rich lake: Lago Caviahue (Patagonia, Argentina). Limnologica 43:475-481.

Beecraft L, Watson SB, Smith REH, 2017. Multi-wavelength Pulse Amplitude Modulated fluorometry (Phyto-PAM) reveals differential effects of ultraviolet radiation on the photosynthetic physiology of phytoplankton pigment groups. Freshwater Biol. 62:72-86.

Bowling LC, Steane MS, Tyler PA, 1986. The spectral distribution and attenuation of underwater irradiance in Tasmanian inland waters. Freshwater Biol. 16:313-335.

Brandão LPM, Staehr PA, Bezerra-Neto JF, 2016. Seasonal changes in optical properties of two contrasting tropical freshwater systems. J. Limnol. 75:508-519. doi: 10.4081/ jlimnol.2016.1359.

Cheng Q, Gao L, Zuo X, Zhong F, 2019. Statistical analyses of spatial and temporal variabilities in total, daytime, and nighttime precipitation indices and of extreme dry/wet association with large-scale circulations of Southwest China, 1961-2016. Atmos. Res. 219:166-182.

Cory RM, Davis TW, Dick GJ, Johengen T, Denef VJ, Berry M, Page SE, Watson SB, Yuhas K, Kling GW, 2016. Seasonal dynamics in dissolved organic matter, hydrogen peroxide, and cyanobacterial blooms in Lake Erie. Front. Mar. Sci. 3:54.

De Lange HJ, 2000. The attenuation of ultraviolet and visible radiation in Dutch inland waters. Aquat. Ecol. 34:215-226.

Dong J, Zhou Q, Gao Y, Gu Q, Li G, Song L, 2018. Long-term effects of temperature and nutrient concentrations on the phytoplankton biomass in three lakes with differing trophic statuses on the Yungui Plateau, China. Intern. J. Limnol. 54:9.

Du Y, Zhang Y, Chen F, Chang Y, Liu Z, 2016. Photochemical reactivities of dissolved organic matter (DOM) in a subalpine lake revealed by EEM-PARAFAC: an insight into the fate of allochthonous DOM in alpine lakes affected by climate change. Sci. Total Environ. 568:216-225.

Forsström L, Rautio M, Cusson M, Sorvari S, Albert R-L, Kumagai M, Korhola A, 2015. Dissolved organic matter concentration, optical parameters and attenuation of solar radiation in high-latitude lakes across three vegetation zones. Ecoscience 22:17-31.

Häder DP, Williamson CE, Wängberg SÅ, Rautio M, Rose KC, Gao K, Helbling EW, Sinha RP, Worrest R, 2015. Effects of $\mathrm{UV}$ radiation on aquatic ecosystems and interactions with other environmental factors. Photochem. Photobiol. Sci. 14:108-126.

Jin X, Tu Q, 1990. [The standard methods for observation and analysis of lake eutrophication, 2nd ed.].[Book in Chinese]. China Environmental Science Press.

Kirk JTO, 2011. Light and photosynthesis in aquatic ecosystems, 3rd ed. Cambridge University Press, Cambridge.

Laurion I, Ventura M, Catalan J, Psenner R, Sommaruga R, 2000. Attenuation of ultraviolet radiation in mountain lakes: factors controlling the among- and within-lake variability. Limnol. Oceanogr. 45:1274-1288.

Li L, Zha Y, 2019. Satellite-based regional warming hiatus in China and its implication. Sci. Total Environ. 648:13941402.

Ma J, Song K, Wen Z, Zhao Y, Shang Y, Fang C, Du J, 2016. Spatial distribution of diffuse attenuation of photosynthetic active radiation and its main regulating factors in inland waters of Northeast China. Remote Sensing 8:964.

Mladenov N, Lípez-Ramos J, Mcknight DM, Rechea I, 2009. Alpine lake optical properties as sentinels of dust deposition and global change. Limnol. Oceanogr.54:2386-2400. 
Mladenov N, Sommaruga R, Morales-Baquero R, Laurion I, Camarero L, Diéguez MC, Camacho A, Delgado A, Torres O, Chen Z, Felip M, Reche I, 2011. Dust inputs and bacteria influence dissolved organic matter in clear alpine lakes. Nat. Comm. 2:405.

Ni Z, Wang S, Jin X, Jiao L, Li Y, 2011. [Study on the evolution and characteristics of eutrophication in the typical lakes on Yunnan-Guizhou Plateau].[Article in Chinese with English abstract]. Acta Scientiae Circumstantiae 31:2681-2689.

Pacheco FS, Roland F, Downing JA, 2014. Eutrophication reverses whole-lake carbon budgets. Inland Waters 4:41-48.

Pérez GL, Llames ME, Lagomarsino L, Zagarese H, 2011. Seasonal variability of optical properties in a highly turbid lake (Laguna Chascomús, Argentina). Photochem. Photobiol. 87:659-670.

Pérez GL, Queimaliños CP, Modenutti BE, 2002. Light climate and plankton in the deep chlorophyll maxima in North Patagonian Andean lakes. J. Plankton Res. 24:591-599.

Pérez GL, Torremorell A, Bustingorry J, Escaray R, Pérez P, Diéguez M, Zagarese H, 2010. Optical characteristics of shallow lakes from the Pampa and Patagonia regions of Argentina. Limnologica 40:30-39.

Pfeifer MT, Koepke P, Reuder J, 2006. Effects of altitude and aerosol on UV radiation. J. Geophys. Res.-Atmos. 111:D01203.

Rose KC, Hamilton DP, Williamson CE, Mcbride CG, Fischer JM, Olson MH, Saros JE, Allan MG, Cabrol N, 2014. Light attenuation characteristics of glacially-fed lakes. J. Geophys. Res.-Biogeo. 119:2014JG002674.

Rose KC, Neale PJ, Tzortziou M, Gallegos CL, Jordan TE, 2019. Patterns of spectral, spatial, and long-term variability in light attenuation in an optically complex sub-estuary. Limnol. Oceanogr. 64:S257-S272.

Rose KC, Williamson CE, Kissman CEH, Saros JE, 2015. Does allochthony in lakes change across an elevation gradient? Ecology 96:3281-3291.

Rose KC, Williamson CE, Saros JE, Sommaruga R, Fischer JM, 2009. Differences in UV transparency and thermal structure between alpine and subalpine lakes: implications for organisms. Photochem. Photobiol. Sci. 8:1244-1256.

Shang Y, Song K, Jacinthe PA, Wen Z, Lyu L, Fang C, Liu G, 2019. Characterization of CDOM in reservoirs and its linkage to trophic status assessment across China using spectroscopic analysis. Jof Hydrol. 576:1-11.

Shi K, Zhang Y, Zhu G, Qin B, Pan D, 2018. Deteriorating water clarity in shallow waters: evidence from long term MODIS and in-situ observations. Int. J. Appl. Earth Observ. Geoinform. 68:287-297.

Shi Y, Zhang L, Li Y, Zhou L, Zhou Y, Zhang Y, Huang C, Li H, $\mathrm{Zhu} \mathrm{G}, 2020$. Influence of land use and rainfall on the optical properties of dissolved organic matter in a key drinking water reservoir in China. Sci. Total Environ. 699:134301.

Sommaruga R, Augustin G, 2006. Seasonality in UV transparency of an alpine lake is associated to changes in phytoplankton biomass. Aquat. Sci. 68:129-141.

Song K, Wen Z, Xu Y, Yang H, Lyu L, Zhao Y, Fang C, Shang Y, Du J, 2018. Dissolved carbon in a large variety of lakes across five limnetic regions in China. J. Hydrol. 563:143154.

Spyrakos E, O'donnell R, Hunter PD, Miller C, Scott M, Simis
SGH, Neil C, Barbosa CCF, Binding CE, Bradt S, Bresciani M, Dall'olmo G, Giardino C, Gitelson AA, Kutser T, Li L, Matsushita B, Martinez-Vicente V, Matthews MW, Ogashawara I, Ruiz-Verdú A, Schalles JF, Tebbs E, Zhang Y, Tyler AN, 2018. Optical types of inland and coastal waters. Limnol. Oceanogr. 63:846-870.

The Editorial Board of Water and Wastewater Monitoring and Analysis Methods of the Ministry of Environmental Protection of the People's Republic of China, 2002. [Water and Wastewater Monitoring and Analysis Methods, 4th ed.].[Book in Chinese]. China Environmental Science Press.

Wang X, Zhu Y, Fan L, Yang P, Yang X, 2009. Spatial-temporal variations of solar global radiation in Yunnan Province during 1961-2007. Adv. Clim. Change Res. 5:29-34.

Xiao Q, Yang K, Hong L, 2018. Remote sensing monitoring and temporal-spatial analysis of surface water body area changes of lakes on the Yunnan-Guizhou Plateau over the past 30 years].[Article in Chinese with English abstract]. J. of Lake Sci. 32:1083-1096.)

Yang K, Yu Z, Luo Y, Zhou X, Shang C, 2019. Spatial-temporal variation of lake surface water temperature and its driving factors in Yunnan-Guizhou Plateau. Water Resour. Res. 55:4688-4703.

Zhang Y, Gao G, Shi K, Niu C, Zhou Y, Qin B, Liu X, 2014. Absorption and fluorescence characteristics of rainwater CDOM and contribution to Lake Taihu, China. Atmos. Environ. 98:483-491.

Zhang Y, Jeppesen E, Liu X, Qin B, Shi K, Zhou Y, Thomaz SM, Deng J, 2017. Global loss of aquatic vegetation in lakes. Earth-Sci. Rev. 173:259-265.

Zhang Y, Liu X, Qin B, Shi K, Deng J, Zhou Y, 2016. Aquatic vegetation in response to increased eutrophication and degraded light climate in Eastern Lake Taihu: implications for lake ecological restoration. Sci. Rep. 6:23867.

Zhang Y, Yin Y, Zhang E, Zhu G, Liu M, Feng L, Qin B, Liu X, 2011. Spectral attenuation of ultraviolet and visible radiation in lakes in the Yunnan Plateau, and the middle and lower reaches of the Yangtze River, China. Photochem. Photobiol. Sci. 10:469-482.

Zhang Y, Zhang B, Wang X, Li J, Feng S, Zhao Q, Liu M, Qin B, 2007a. A study of absorption characteristics of chromophoric dissolved organic matter and particles in Lake Taihu, China. Hydrobiologia 592:105-120.

Zhang Y, Zhang E, Liu M, Wang X, Qin B, 2007b. Variation of chromophoric dissolved organic matter and possible attenuation depth of ultraviolet radiation in Yunnan Plateau lakes. Limnology 8:311-319.

Zhang Y, Zhou Y, Shi K, Qin B, Yao X, Zhang Y, 2018. Optical properties and composition changes in chromophoric dissolved organic matter along trophic gradients: implications for monitoring and assessing lake eutrophication. Water Res. 131:255-263.

Zhou P, Chen Z, 2008. [Analysis of the spatio-temporal characteristics of UV-B strength change over the Yunnan Plateau].[Article in Chinese with English abstract] J. of Nat. Resour. 23:487-493.

Zhou Q, Wang W, Huang L, Zhang Y, Qin J, Li K, Chen L, 2019. Spatial and temporal variability in water transparency in Yunnan Plateau lakes, China. Aquat. Sci. 81:36. 
Zhou Q, Zhang Y, Li K, Huang L, Yang F, Zhou Y, Chang J, 2018. Seasonal and spatial distributions of euphotic zone and long-term variations in water transparency in a clear oligotrophic Lake Fuxian, China. J. Environm. Sci. 72:185197.

Zhou Q, Zhang Y, Lin D, Shan K, Luo Y, Zhao L, Tan Z, Song L, 2016a. The relationships of meteorological factors and nutrient levels with phytoplankton biomass in a shallow eutrophic lake dominated by cyanobacteria, Lake Dianchi from 1991 to 2013. Environ. Sci. Pollut. Res. 23:1561615626.

Zhou Y, Zhang Y, Jeppesen E, Murphy KR, Shi K, Liu M, Liu $\mathrm{X}$, Zhu G, 2016b. Inflow rate-driven changes in the composition and dynamics of chromophoric dissolved organic matter in a large drinking water lake. Water Res. 100:211-221. 